HortSCIENCE 27(3):230-233. 1992.

\title{
Response of 'Tifway' Bermudagrass to Rate and Frequency of Flurprimidol and Paclobutrazol Application
}

\author{
B.J. Johnson ${ }^{1}$ \\ Department of Agronomy, University of Georgia, Georgia Station, \\ Griffin, GA 30223-1797 \\ Additional index words. plant growth regulators, turfgrass injury, vegetative \\ suppression, Cynodon transvaalensis $\times$ C. dactylon
}

\begin{abstract}
A field experiment was conducted for 2 years to determine the effects of rate and time interval for repeated applications of the plant growth regulators (PGR) flurprimidol and paclobutrazol on vegetative suppression of 'Tifway' bermudagrass [Cynodon transvaalensis Burtt-Davy $\times$ C. dactylon (L.) Pers.]. Suppression of vegetative growth of this grass was generally the same when either flurprimidol or paclobutrazol was applied twice after a 2-, 3-, or 4-week interval. The duration of growth suppression was also similar after initial application with flurprimidol at $0.84 \mathrm{~kg} \cdot \mathrm{ha}^{-1}$ and repeated at 0.28 to $0.84 \mathrm{~kg} \cdot \mathrm{ha}^{-1}$ or with paclobutrazol applied initially at $1.1 \mathrm{~kg} \cdot \mathrm{ha}^{-1}$ and repeated at 0.56 to $1.1 \mathrm{~kg}^{-1} \mathrm{ha}^{-1}$. Both PGRs caused slight to moderate turfgrass injury at these rates, but the injury was temporary and the grass had fully recovered by 10 weeks. Chemical names used: $\alpha$-(1-methylethyl)- $\alpha$-[4-(trifluoromethoxy)-phenyl]-5pyrimidinemethanol (flurprimidol); $( \pm)-\left(\mathbf{R}^{*} \mathbf{R}^{*}\right) \beta-[(4-\mathrm{chlorophenyl})-\mathrm{methyl}]-\alpha-(1,1-$ dimethylethyl)-1H-1,2,4-triazole-l-ethanol (paclobutrazol).
\end{abstract}

Plant growth regulators (PGRs) are used on turf for their potential to reduce vegetative growth and the number of required mowings. Batten (1983) reported the number of mowings was reduced up to $50 \%$ for 5 to 8 weeks after application of PGRs. However, PGR use on turfgrasses is limited by the potential for turf injury and inconsistent response of turfgrass to PGRs (Christians, 1985).

Flurprimidol applied in June reduced vertical growth of common bermudagrass $[C y$ nodon dactylon (L.) Pers.] in North Carolina (DiPaola et al., 1985) and 'Tifway' bermu-

Received for publication 27 Mar. 1991. Accepted for publication 17 Oct. 1991. Supported by state and Hatch Act funds allocated to the Georgia Agr. Expt. Stas. I acknowledge J. Davis, station statistician, for his cooperation and T. Dinkins and M. Gilmer for technical assistance. The cost of publishing this paper was defrayed in part by the payment of page charges. Under postal regulations, this paper therefore must be hereby marked advertisement solely to indicate this fact. ${ }^{1}$ Professor. dagrass in Georgia (Johnson, 1988, 1989, 1990). This type of reduction will be referred to as suppression. The suppression of 'Tifway' bermudagrass from a single $0.84 \mathrm{~kg}$ flurprimidol/ha treatment in Georgia ranged from 0 to 4 weeks. Suppression generally was not improved when flurprimidol was applied at $0.56 \mathrm{~kg} \cdot \mathrm{ha}^{-1}$ in each of two applications at 2- to 3-week intervals (Johnson, 1990). However, when 'Tifway' was treated with flurprimidol at $0.21 \mathrm{~kg} \cdot \mathrm{ha}^{-1}$ on 30 May and the application was repeated after a 3week interval until 7 Aug. for a total 0.84 $\mathrm{kg} \cdot \mathrm{ha}^{-1}$, effective growth suppression occurred from 28 June through 3 Aug. (Johnson, 1988). Paclobutrazol applied at 1.1 $\mathrm{kg} \cdot \mathrm{ha}^{-1}$ as a single treatment suppressed 'Tifway' bermudagrass for 3 weeks (Johnson, 1990). The suppression increased by only 1 week when paclobutrazol was applied twice $\left(1.1+0.56 \mathrm{~kg} \cdot \mathrm{ha}^{-1}\right)$ at 2- to 3-week intervals (Johnson, 1990).

For PGRs to be effective, they should not cause undesirable injury to the turf, i.e., moderate to severe leaf discoloration or plant 
Table 1. Influence of rate and time interval between repeat applications of flurprimidol and paclobutrazol on suppression of vegetative height of 'Tifway' bermudagrass at Griffin, Ga.

Plant growth regulators ${ }^{\mathbf{z}}$

\begin{tabular}{|c|c|c|c|c|c|c|c|}
\hline \multirow[b]{3}{*}{ Name } & \multicolumn{3}{|c|}{ Application } & \multicolumn{4}{|c|}{ Suppression $(\%)^{\mathrm{y}}$} \\
\hline & \multirow{2}{*}{$\begin{array}{c}\text { Initial } \\
\left(\mathrm{kg} \cdot \mathrm{ha}^{-1}\right)\end{array}$} & \multirow{2}{*}{$\begin{array}{c}\text { Second } \\
\left(\mathrm{kg} \cdot \mathrm{ha}^{-1}\right)\end{array}$} & \multirow{2}{*}{$\begin{array}{c}\text { Time } \\
\text { interval } \\
\text { (wks) }\end{array}$} & \multicolumn{4}{|c|}{ Weeks after initial treatment } \\
\hline & & & & 3 & 5 & 6 & 7 \\
\hline \multirow[t]{7}{*}{ Flurprimidol } & 0.84 & -.- & 0 & 16 & 3 & 5 & 3 \\
\hline & 0.84 & 0.56 & $0+2$ & 26 & 16 & 25 & 17 \\
\hline & 0.84 & 0.28 & $0+2$ & 19 & 12 & 15 & 7 \\
\hline & 0.84 & 0.56 & $0+3$ & $19^{x}$ & 4 & 24 & 14 \\
\hline & 0.84 & 0.28 & $0+3$ & $15^{\mathrm{x}}$ & 6 & 11 & 2 \\
\hline & 0.84 & 0.56 & $0+4$ & $19^{x}$ & 2 & 17 & 14 \\
\hline & 0.84 & 0.28 & $0+4$ & $18^{x}$ & 11 & 19 & 12 \\
\hline & & & & 19 & 15 & 15 & 16 \\
\hline \multicolumn{8}{|c|}{ Main effect means } \\
\hline \multicolumn{8}{|c|}{ Rates $\left(\mathrm{kg} \cdot \mathrm{ha}^{-1}\right)$} \\
\hline $0.84+0$ & & & & 22 & 7 & 22 & 15 \\
\hline $0.84+0$ & & & & 16 & 12 & 19 & 22 \\
\hline $0.84+0$ & & & & 18 & 9 & 15 & 7 \\
\hline \multicolumn{8}{|c|}{ Intervals (weeks) } \\
\hline $0+2$ & & & & 20 & 14 & 20 & 12 \\
\hline $0+3$ & & & & 17 & 9 & 18 & 9 \\
\hline $0+4$ & & & & 18 & 6 & 18 & 3 \\
\hline \multirow[t]{7}{*}{ Paclobutrazol } & 1.1 & $\cdots$ & 0 & 11 & 3 & 12 & 2 \\
\hline & 1.1 & 1.1 & $0+2$ & 23 & 18 & 27 & 17 \\
\hline & 1.1 & 0.56 & $0+2$ & 19 & 19 & 26 & 11 \\
\hline & 1.1 & 1.1 & $0+3$ & $23^{x}$ & 9 & 19 & 15 \\
\hline & 1.1 & 0.56 & $0+3$ & $21^{x}$ & 13 & 25 & 16 \\
\hline & 1.1 & 1.1 & $0+4$ & $20^{x}$ & 3 & 16 & 7 \\
\hline & 1.1 & 0.56 & $0+4$ & $17^{x}$ & 10 & 25 & 16 \\
\hline LSD $(0.05)$ & & & & 14 & 17 & 12 & 16 \\
\hline \multicolumn{8}{|c|}{ Main effect means } \\
\hline \multicolumn{8}{|c|}{ Rates $\left(\mathrm{kg} \cdot \mathrm{ha}^{-1}\right)$} \\
\hline $1.1+1$ & & & & 22 & 9 & 21 & 13 \\
\hline $1.1+0.8$ & & & & 17 & 7 & 20 & 15 \\
\hline $1.1+0$. & & & & 19 & 14 & 25 & 15 \\
\hline \multicolumn{8}{|c|}{ Intervals (weeks) } \\
\hline $0+2$ & & & & 20 & 16 & 26 & 13 \\
\hline $0+3$ & & & & 20 & 9 & 20 & 16 \\
\hline $0+4$ & & & & 18 & $6^{*}$ & 20 & 13 \\
\hline
\end{tabular}

zTreatments were applied 31 May, and 14, 22, and 28 June \pm 1 day 1989 and 1990 or at 0, 2, 3, and 4 weeks after the initial application, respectively.

y Vegetative height ratings are means of five measurements within four replications for each of 2 years and based on percent suppression related to plots not treated with plant growth regulators.

*Second application was made after ratings were recorded.

*The vegetative suppression was higher at 5 WAT with paclobutrazol at $0+2$ weeks (averaged across rates) than when applied at $0+4$ weeks. There were no other differences.

desiccation, while reducing foliar growth. Injury of 'Tifway' bermudagrass ranged from minor to severe leaf discoloration, with some plant desiccation, when flurprimidol was applied at $0.84 \mathrm{~kg} \cdot \mathrm{ha}^{-1}$ (Johnson, 1980, 1989, 1990) and showed minor leaf discoloration when paclobutrazol was applied at $1.1 \mathrm{~kg} \cdot \mathrm{ha}^{-1}$ (Johnson, 1990).

An experiment was initiated with flurprimidol and paclobutrazol to determine the effects of application rates and time interval between applications on duration of growth suppression and 'Tifway' bermudagrass injury.

Fiurprimidol and paclobutrazol were applied as a spray to established 'Tifway' bermudagrass at Griffin, Ga., during 1989 and 1990. The initial PGR application was made on 31 May and repeated (interval) on 14 June ( 2 weeks), 22 June ( 3 weeks), or 28 June (4 weeks) \pm 1 day. For flurprimidol, the initial application was $0.84 \mathrm{~kg} \cdot \mathrm{ha}^{-1}$, followed by $0.28,0.43$, or $0.56 \mathrm{~kg} \cdot \mathrm{ha}^{-1}$ as repeated applications for total rates of $1.12,1.27$, and $1.40 \mathrm{~kg} \cdot \mathrm{ha}^{-1}$, respectively. For paclobutra- zol, the initial application was $1.1 \mathrm{~kg} \cdot \mathrm{ha}^{-1}$, followed by $0.56,0.84$, or $1.1 \mathrm{~kg} \cdot \mathrm{ha}^{-1}$ for total rates of $1.66,1.94$, and $2.20 \mathrm{~kg} \cdot \mathrm{ha}^{-1}$, respectively. Results for flurprimidol at 0.84 $+0.43 \mathrm{~kg} \cdot \mathrm{ha}^{-1}$ and paclobutrazol at $1.1+$ $0.84 \mathrm{~kg} \cdot \mathrm{ha}^{-1}$ were omitted from parts of the tables since their effect was similar to the other treatments. A single application of flurprimidol at $0.84 \mathrm{~kg} \cdot \mathrm{ha}^{-1}$, paclobutrazol at $1.1 \mathrm{~kg} \cdot \mathrm{ha}^{-1}$, and an untreated control were included. All PGRs were applied to different plots each year as a broadcast spray in 375 liters of water/ha.

The soil type was an Appling loamy sand (clayey, kaolinitic, Thermic Typic Hapludult) with $2.2 \%$ organic matter, $79 \%$ sand, $14 \%$ silt, and $7 \%$ clay. Soil $\mathrm{pH}$ was 5.7 . A soil test indicated that $\mathrm{P}$ was high (48 $\left.\mathrm{mg} \cdot \mathrm{kg}^{-1}\right)$ and $\mathrm{K}$ was low $\left(59 \mathrm{mg} \cdot \mathrm{kg}^{-1}\right)$.

Each year 'Tifway' bermudagrass was fertilized uniformly (kg-ha-r) with $50 \mathrm{~N}-22 \mathrm{P}$ $42 \mathrm{~K}$ in mid-April. Additional $\mathrm{N}$ was applied at $50 \mathrm{~kg} \cdot \mathrm{ha}^{-1}$ in mid-May. Bermudagrass was irrigated as needed to maintain normal growth. Plot size was $1.5 \times 3 \mathrm{~m}$. The grass was mowed with a reel mower at a height of 3 $\mathrm{cm}$, and clippings were removed 1 day before initial PGR treatments and each week after plant height measurements were made. Half of the PGR-treated plots were mowed weekly; the other half was not mowed during the study.

Vegetative heights of bermudagrass were taken from soil surface to tip of leaves, and injury and density ratings were estimated visually. Five plant height measurements were made within each replication before mowing at weekly intervals from 2 to 10 weeks after the first treatment (WAT). Similar measurements were made in nonmowed plots at 4 , 6,8 , and 10 WAT. All height data are reported as percent suppression when compared with nontreated grass. The injury ratings were made at weekly intervals beginning at 2 WAT and continuing until 10 WAT. The ratings were based on $0=$ no injury, $1 \%$ to $15 \%=$ minor leaf discoloration, $16 \%$ to $30 \%$ $=$ moderate discoloration with some plant desiccation, $31 \%$ and higher $=$ moderate to severe leaf discoloration and plant desiccation, and $100 \%=$ complete kill. Turf density ratings were made at weekly intervals from 5 to 10 WAT and based on $1=$ no turf cover and $10=$ complete uniform cover.

The experiment was analyzed as a completely randomized split plot with repeated measures at weekly intervals. Year was treated as the main plot with subplot application rate and timing in a factorial arrangement. Preliminary analysis showed that neither year nor any of its interactions were significant at $P=0.05$ (SAS Institute, 1982); therefore, both years' data were pooled across years for subsequent analysis. Date of remeasurement, and associated interactions, proved to be highly significant $(P<0.001)$; consequently, the data were analyzed within remeasurement date. There were no application rate $\times$ application time interactions $(P=$ $0.05)$. Means for each PGR were separated by LSD at $P=0.05$. Contrasts were made across rates and interval combinations.

There was no difference in suppression of 'Tifway' bermudagrass when flurprimidol was applied in two applications, regardless of total rate or interval between treatments (Table 1). This response is shown by nonsignificant differences between rates (averaged across intervals of treatment) and treatment intervals (averaged across rates). It is necessary to apply flurprimidol initially at $0.84 \mathrm{~kg} \cdot \mathrm{ha}$, but the rate of the second application can vary from 0.28 to $0.56 \mathrm{~kg} \cdot \mathrm{ha}^{-1}$ for maximum growth suppression. However, since flurprimidol applied at $0.84+0.28 \mathrm{~kg} \cdot \mathrm{ha}^{-1}$ injured 'Tifway' bermudagrass less at 7 to 10 WAT than did $0.84+0.56 \mathrm{~kg} \cdot \mathrm{ha}^{-1}(\mathrm{Ta}-$ ble 2), the lower rate should be used. Turf density was also better in plots when the second application was $0.28 \mathrm{~kg} \cdot \mathrm{ha}^{-1}$ rather than $0.56 \mathrm{~kg} \cdot \mathrm{ha}^{-1}$.

The injury of 'Tifway' bermudagrass treated with flurprimidol varied with the timing of the second application (averaged across rates) (Table 2). The injury was less at 5 WAT when the second flurprimidol treatment was applied after a 4-week rather than 
Table 2. Influence of rate and time interval between repeat applications of flurprimidol and paclobutrazol on injury and density of 'Tifway' bermudagrass at Griffin, Ga.

\begin{tabular}{|c|c|c|c|c|c|c|c|c|}
\hline \multicolumn{4}{|c|}{ Plant growth regulators } & \multirow{2}{*}{\multicolumn{4}{|c|}{ Turfgrass injury (\%) }} & \\
\hline \multirow[b]{3}{*}{ Name } & \multicolumn{3}{|c|}{ Application } & & & & & $(1 \text { to } 10)^{x}$ \\
\hline & \multirow{2}{*}{$\begin{array}{c}\text { Initial } \\
\left(\mathrm{kg}^{2} \mathrm{ha}^{-1}\right)\end{array}$} & \multirow{2}{*}{$\begin{array}{c}\text { Second } \\
\left(\mathrm{kg} \cdot \mathrm{ha}^{-1}\right)\end{array}$} & \multirow{2}{*}{$\begin{array}{c}\text { Time } \\
\text { interval } \\
\text { (wks) }\end{array}$} & \multicolumn{5}{|c|}{ Weeks after initial treatment } \\
\hline & & & & 5 & 7 & 9 & 10 & 10 \\
\hline Untreated & $\ldots$ & --- & $\ldots$ & 0 & 0 & 0 & 0 & 10.0 \\
\hline \multirow[t]{7}{*}{ Flurprimidol } & 0.84 & --- & 0 & 4 & 1 & 0 & 0 & 9.8 \\
\hline & 0.84 & 0.56 & $0+2$ & 24 & 21 & 14 & 9 & 8.8 \\
\hline & 0.84 & 0.28 & $0+2$ & 13 & 7 & 0 & 1 & 9.7 \\
\hline & 0.84 & 0.56 & $0+3$ & 17 & 20 & 14 & 10 & 8.8 \\
\hline & 0.84 & 0.28 & $0+3$ & 12 & 6 & 4 & 1 & 9.8 \\
\hline & 0.84 & 0.56 & $0+4$ & 8 & 17 & 18 & 11 & 8.5 \\
\hline & 0.84 & 0.28 & $0+4$ & 9 & 9 & 6 & 8 & 9.3 \\
\hline \multicolumn{4}{|c|}{$\operatorname{LSD}(0.05)$} & 12 & 13 & 10 & 9 & 0.8 \\
\hline \multicolumn{9}{|c|}{ Main effect means } \\
\hline \multicolumn{9}{|c|}{ Rates $\left(\mathrm{kg} \cdot \mathrm{ha}^{-1}\right)$} \\
\hline \multicolumn{2}{|c|}{$0.84+0.56$} & & & 16 & 19 & 15 & 10 & 8.7 \\
\hline \multicolumn{2}{|c|}{$0.84+0.43$} & & & 17 & 18 & 13 & 7 & $9.0^{\circ}$ \\
\hline \multirow{2}{*}{\multicolumn{4}{|c|}{$0.84+0.28$}} & 11 & 7 & 4 & 3 & 9.6 \\
\hline \multirow{2}{*}{\multicolumn{9}{|c|}{$\begin{array}{l}\text { Orthogonal comparisons } \\
0.84+0.56\end{array}$}} \\
\hline & & & & & & & & \\
\hline \multicolumn{2}{|c|}{ vs. $0.84+0.43$} & & & NS & NS & NS & NS & NS \\
\hline vs. 0.8 & $4+0.28$ & & & NS & $*$ & $*$ & * & $*$ \\
\hline Intervals (w & eeks) & & & & & & & \\
\hline $0+2$ & & & & 19 & 14 & 7 & 5 & 9.3 \\
\hline $0+3$ & & & & 15 & 14 & 10 & 6 & 9.2 \\
\hline $0+4$ & & & & 10 & 16 & 14 & 10 & 8.8 \\
\hline Orthogonal & comparison & & & & & & & \\
\hline vs. 0 & -3 & & & NS & NS & NS & NS & NS \\
\hline vs. 0 & & & & $*$ & NS & $*$ & $*$ & $*$ \\
\hline Untreated & --. & -.. & --- & 0 & 0 & 0 & 0 & 10.0 \\
\hline Paclobutrazol & 1.1 & ... & 0 & 6 & 5 & 3 & 3 & 9.6 \\
\hline & 1.1 & 1.1 & $0+2$ & 19 & 27 & 17 & 10 & 8.6 \\
\hline & 1.1 & 0.56 & $0+2$ & 13 & 16 & 12 & 7 & 9.1 \\
\hline & 1.1 & 1.1 & $0+3$ & 9 & 25 & 20 & 17 & 8.4 \\
\hline & 1.1 & 0.56 & $0+3$ & 15 & 19 & 14 & 13 & 8.5 \\
\hline & 1.1 & 1.1 & $0+4$ & 7 & 18 & 17 & 13 & 8.6 \\
\hline & 1.1 & 0.56 & $0+4$ & 8 & 18 & 13 & 14 & 8.7 \\
\hline LSD $(0.05)$ & & & & 9 & 12 & 11 & 11 & 1.0 \\
\hline Main effect $m$ & Eans & & & & & & & \\
\hline Rates $(\mathrm{kg} \cdot \mathrm{h}$ & & & & & & & & \\
\hline $1.1+1$ & & & & 11 & 23 & 18 & 14 & 8.5 \\
\hline $1.1+0$ & & & & 10 & 16 & 11 & 10 & 8.8 \\
\hline $1.1+0$ & & & & 12 & 15 & 11 & 11 & 8.7 \\
\hline Orthogonal & comparison & & & & & & & \\
\hline $1.1+1$ & & & & & & & & \\
\hline vs. 1.1 & +0.84 & & & NS & * & * & NS & NS \\
\hline vs. 1.1 & +0.56 & & & NS & * & * & NS & NS \\
\hline Intervals (w & eks) & & & & & & & \\
\hline $0+2$ & & & & 15 & 20 & 12 & 9 & 8.9 \\
\hline $0+3$ & & & & 10 & 19 & 14 & 13 & 8.6 \\
\hline $0+4$ & & & & 7 & 18 & 17 & 12 & 8.6 \\
\hline Orthogonal & comparison & & & & & & & \\
\hline $0+2$ & & & & & & & & \\
\hline vs. 0 & & & & * & NS & NS & NS & NS \\
\hline vs. 0 & 4 & & & ** & NS & NS & NS & NS \\
\hline
\end{tabular}

xPlant growth regulator applications were made 31 May, and 14, 22, and 28 June \pm 1 day 1989 and 1990 or at $0,2,3$, and 4 weeks after the initial application, respectively.

'Turfgrass injury ratings were made at times indicated after first plant growth regulator application and based on $0=$ no injury, $\geq 30=$ unacceptable, and $100=$ complete kill. Data are the means of four observations each year.

'Turf density ratings were made at 10 weeks after treatment and based on $1=$ no turf, $8.5=$ acceptable, and $10=$ complete uniform cover. Data are the means of four observations for each year.

*,**Significant at 0.05 and 0.01 levels, respectively.

a 2-week interval. Turf injury at 9 and 10 WAT was higher when the second application was made after 4 weeks than after 2 weeks. The higher injury also reduced the density of the turf. The lower injury from flurprimidol at 5 WAT when applied after a 4-week interval was related to the elapse of insufficient time for the PGR to achieve its
When paclobutrazol was applied in two applications, there was no difference in suppression of 'Tifway' bermudagrass regardless of total rate (Table 1). This is shown by nonsignificant comparisons of rates when averaged across treatment intervals. The interval between paclobutrazol treatments also did not influence suppression of bermudagrass when averaged across rates, except at 5 WAT. The suppression was highest when the second paclobutrazol treatment was made after 2 rather than 4 weeks. The poor suppression from delayed treatment at 4 weeks probably resulted from dissipation of the PGR from the first application and insufficient elapse of time after the 4-week treatment for the PGR to be effective at 5 weeks. By 6 WAT, there was no difference in suppression due to interval of PGR treatments.

Paclobutrazol applied twice at $1.1 \mathrm{~kg} \cdot \mathrm{ha}^{-1}$ (averaged across treatment intervals) injured turf more than when applied initially at 1.1 $\mathrm{kg} \cdot \mathrm{ha}^{-1}$ and followed by 0.56 or $0.84 \mathrm{~kg} \cdot \mathrm{ha}^{-1}$ (Table 2).

Multiple applications of either flurprimidol or paclobutrazol suppressed vegetative growth of 'Tifway' bermudagrass longer than a single application. Both PGRs suppressed vegetative growth from 3 to 7 weeks after the initial treatment.

Two applications of flurprimidol and paclobutrazol significantly suppressed growth of unmowed 'Tifway' bermudagrass from 4 to 10 WAT (data not shown). However, unmowed 'Tifway' bermudagrass will not be a high-quality turf. Bermudagrass maintains green growth in upper leaves due to senescence of the lower leaves; thus, a delay in mowing will cause scalping and result in a lower-quality turf when cut at the original height. Bermudagrass in PGR-treated plots produced less clippings and reduced the number of mowings by $30 \%$ to $50 \%$ (using the rule that grass should never be taller than one-third of the original growth) during 6 WAT when compared with untreated turf. Therefore, mowing should be included with PGRs to maintain an acceptable quality of 'Tifway' bermudagrass.

These results show that either flurprimidol or paclobutrazol suppresses vegetative growth of 'Tifway' bermudagrass up to 7 WAT without undesirable injury or reduction in turf density. For maximum suppression, flurprimidol should be applied initially at 0.84 $\mathrm{kg} \cdot \mathrm{ha}^{-1}$ and followed by $0.28 \mathrm{~kg} \cdot \mathrm{ha}^{-1}$, and paclobutrazol should be applied initially at $1.1 \mathrm{~kg} \cdot \mathrm{ha}^{-1}$ and followed by $0.56 \mathrm{~kg} \cdot \mathrm{ha}^{-1}$. The suppression was as good when PGR treatments were repeated after a 2 -week interval as when the second treatment was delayed until 3 or 4 weeks.

\section{Literature Cited}

Batten, S.M. 1983. Growth regulators-New tools for the '80's. USGA Green Section 21(63):13. differences in injury from different intervals of flurprimidol treatment, it was within an acceptable level $(<30 \%)$ and the turf fully recovered. The injury to turf treated with flurprimidol at $0+2$ weeks was the highest at 5 WAT, while the injury from $0+4$ weeks was the highest at 9 and 10 WAT.
Christians, N.E. 1985. Response of Kentucky bluegrass to four growth retardants. J. Amer. Soc. Hort. Sci. 110:765-769.

DiPaola, J.M., W.B. Gilbert, and W.M. Lewis. 1985. Turfgrass response to growth retardants. Fact Sheet Fla. Turf Dig. 2(1). 
Johnson, B.J. 1988. Influence of nitrogen in the response of 'Tifway' bermudagrass (Cynodon dactylon) to flurprimidol. Weed Technol. 2:5558 .
Johnson, B.J. 1989. Response of bermudagrasses (Cynodon spp.) to plant growth regulators. Weed Technol. 3:440-444.

Johnson, B.J. 1990. Response of bermudagrass
(Cynodon spp.) cultivars to multiple plant growth regulator treatments. Weed Technol. 4:549-554.

SAS Institute, Inc. 1982. SAS users guide. SAS Institute, Inc., Cary, N.C. 